IRA-International Journal of Education \& Multidisciplinary Studies ISSN 2455-2526; Vol.06, Issue 01 (2017)

Pg. no. 9-30

Institute of Research Advances http://research-advances.org/index.php/IJEMS

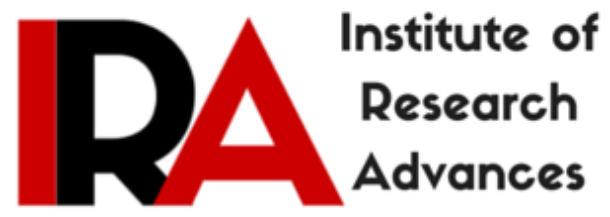

\title{
An Investigation of Secondary Schools' Readiness towards the Implementation of Life Skills Education: A Study of Trans- Nzoia County, Kenya
}

\author{
R. S. Simiyu ${ }^{1}$, E. Kirwok ${ }^{2}$ and R. W. Thinguri ${ }^{3}$ \\ ${ }^{1,2,3}$ Mount Kenya University, Kenya.
}

Type of Review: Peer Reviewed.

DOI: http://dx.doi.org/10.21013/jems.v6.n1.p2

\section{How to cite this paper:}

Simiyu, R., Kirwok, E., \& Thinguri, R. (2017). An Investigation of Secondary Schools' Readiness towards the Implementation of Life Skills Education: A Study of Trans-Nzoia County, Kenya. IRA International Journal of Education and Multidisciplinary Studies (ISSN 2455-2526), 6(1), 9-30. doi:http://dx.doi.org/10.21013/jems.v6.n1.p2

(C) Institute of Research Advances

\section{(oc) EY-NC}

This work is licensed under a Creative Commons Attribution-Non Commercial 4.0 International License subject to proper citation to the publication source of the work.

Disclaimer: The scholarly papers as reviewed and published by the Institute of Research Advances (IRA) are the views and opinions of their respective authors and are not the views or opinions of the IRA. The IRA disclaims of any harm or loss caused due to the published content to any party. 


\section{ABSTRACT}

Life skills education was introduced by the Kenya government to replace the HIV and AIDS education which was not positively perceived by its implementers. The purpose of this study was to investigate Secondary schools' readiness towards the implementation of life skills education in Trans-Nzoia County. The main objectives were to determine teachers' training on life skills education implementation in Trans-Nzoia County, to assess the availability of teaching and learning materials and infrastructure for the implementation of life skills education in TransNzoia County, to evaluate teachers' attitude towards the implementation of life skills education in secondary schools of Trans-Nzoia County, and to establish school management attitude towards the implementation of life skills education in secondary schools of Trans-Nzoia County. The study was guided by Work readiness theory by Catherine, Walker, Mathew and Cathy. This study employed concurrent triangulation study design with mixed methodology, where a target population of 2,234 teachers was studied. The study used concurrent sampling technique. Probability sampling with a simple random sample was used to sample thirty percent of schools. It further purposively sampled out thirty percent of secondary schools principals, deputy principals, guidance and counselling heads of department and teachers assigned to teach life skills who participated in the study. Instruments of data collection included interview schedule, observation guide and document analysis guide. A pilot study was carried out to establish the reliability of research instruments. Data was analyzed descriptively and thematically. The study was significant in contribution to the formulation of policies for life skills education in secondary schools, recognition of life skills education in the development of the nation by the stake holders, consideration of school management and teacher factors that are related to the teaching of life skills education by curriculum developers and also serve as a reference material to potential researchers in the related field of study. The findings of the study indicated inadequate training of teachers in life skills education, inadequate use of teaching learning materials, some element of unwillingness by teachers in the implementation of life skills education in secondary schools of Trans-Nzoia County. There was also inadequate supervision and support towards teachers by administrators towards the implementation of life skills education in Secondary schools of TransNzoia County. The recommendations were that the government should put a policy in place as an affirmative action to train teachers in the implementation of life skills education. Kenya Institute of Curriculum Development should review the implementation programme in terms of time and curricular and nationally evaluate the subject.

Keywords: Life skills education implementation, secondary school teachers, secondary schools

\section{Introduction}

Life skills for children and adolescence have for a long time been neglected in the programs throughout Eastern and Southern African region (ESAR), where the formal education system has been prioritizing on imparting academic knowledge (Greenberg, 2008). During the revision of the curriculum in 2003 in Kenya, life skills was integrated and infused into various subjects. Subsequently, Kenya Institute of Education (KIE) which is now Kenya Institute of Curriculum Development (KICD) incorporated life skills into teaching and learning materials, besides undertaking capacity building programs for primary and secondary school teachers, to mainstream life skills education. This was as a result of the monitoring exercise on HIV and AIDS project by Kenya Institute of Curriculum Development, which established that there existed a gap between knowledge and behavior change among the learners. Life skills education was hence seen to be the stop gap measure (Wasamu, 2011). 
During the life skills education actions to achieving millennium development goals for poverty reduction and Education for All, it was noted that Kenya did not have adequate policy to support the development of life skills early in the life of its youth. This is now considered inadequate without adequate psycho-social skills that would prepare young people for the complex challenges that exist in the world today (MOE, 2005).

Kenya Institute of Education (KIE) which is now Kenya Institute of Curriculum Development (KICD) conducted a monitoring exercise on the implementation of life skills education in Kwale District in 2005, and a study tour to Zimbabwe and Malawi by education officers. This was followed by the national life skills stakeholders' conference held in July 2006, and the National life skills stakeholders' forum held in Kenya Institute of Curriculum Development to appraise stakeholders on the curriculum. A key recommendation from the national forum was that life skills education should be taught as a stand- alone subject in primary and secondary levels (MOE, 2009).

The Kenyan government introduced the teaching of life skills education in both primary and secondary schools in 2008, as a non-examinable stand-alone subject. The curriculum development in the teaching of life skills education is not participatory to include the faith based organizations, parents, Non-Governmental organizations and ministry of Education (Kelin, 2011).

UNICEF (2008) defines life skills as "psychosocial abilities for adaptive and positive behavior that enables individuals to deal effectively with the demands and challenges of everyday life." The skills can be grouped into three broad categories, namely cognitive skills for analyzing and using information, personal skills for developing personal agency and self-management and interpersonal skills for communicating and interacting effectively with others. In studies on life skills in globally what tends to emerge is that there is yet no consensus on the conceptualization of the term life skills education (UNICEF, 2012).

Some schools in South Africa were not ready to implement life skills education due to the principals' negative attitude. Prinsloo (2007), found that lack of commitment by some principals to make the programme a success at the school level was a challenge in the implementation of life skills education in South Africa. Some Principals indicated difficulty in supporting implementation of life skills education because learners were "careless, irresponsible and had no mission or vision in life" (Prinsloo, 2007).

Githinji (2007), in her study on perceptions of primary school teachers and pupils on adequacy of HIV and AIDS life skills education in Nairobi and Thika Districts, found that there were inadequate teaching, insufficient knowledge and lack of enough life skills education in both teachers and pupils. The study also found that teachers found it difficult to explain and teach some of the ways in which AIDS is spread. Some of the HIV and AIDS life skills teachers lacked training and adequate time. Cultural differences resistance from parents, and lack of support from the administration were other problems that teachers condoned with.

The government of Kenya introduced the teaching of life skills in both primary and secondary schools in 2008, as a stand-alone none examinable subject. This was after the Kenya Institute of Education which is now Kenya Institute of Curriculum Development (KICD) established that there existed a gap between knowledge and behavior change among learners with the implementation of life skills education through integration and infusion into various subjects. (Wasamu, 2011).The intention was to empower students with psychosocial competencies that would help them make informed decisions, solve problems think critically, communicate effectively build healthy relationships, empathize with those in need and manage their life in a 
healthy and productive manner including the fight against HIV and AIDS infections. It is a comprehensive behavior change approach that concentrates on the development of the psychosocial skills needed for life. The course goes beyond information to the development of the whole individual (MOE, 2008).

It is the teacher who decides the arrangement of learning experiences, and the methods of content presentation and does most of the evaluation. The teacher therefore initiates, develops and directs students learning (Omulando and Shuindu, 1992). As quoted by Abobo and Orodho (2014), a study conducted by Orodho (2013), in public secondary schools in Kenya demonstrated that schools do not have adequate and appropriate instructional materials for effective implementation of the curriculum.

The lack of consensus on the concept of life skills not withstanding Education for All (EFA) goal three, stresses the need to ensure that all the young people and adults are met through equitable access to appropriate learning and life skills.

Coincidentally, the republic of Kenya in collaboration during the end of decade evaluation (EDA) of achievement of Education for All (EFA) goals in 2012, conceded that these goals remains a difficult area to conceptualize and measure due to the complex nature of life skills and lifelong learning and the fact that quantitative benchmarks of these programs are not yet well defined nationally and internationally. As a result of this complex scenario, while assessing the achievement of Education for All (EFA) in Kenya the Evaluation team focused on three life skills areas. These were HIV and AIDS education, peace education and Technical, Industrial and Vocational Training (TIVET); arguing that these three areas were critical in enhancing the social economic development of the country in the wake of rising HIV infections, recent challenges to social cohesion and high unemployment rate. The evaluation team went further to lament that in the absence of policy frameworks and elaborate curricular and programs that addresses life skills issues holistically, a shared understanding of this concept across formal, non-formal and informal education in Kenya is lacking (MOE/UNICEF, 2012).

In their assessment of the level of preparedness of teachers and school managers in the implementation of life skills education in secondary schools of Trans-Nzoia West District, (Abobo and Orodho, 2014), established that most teachers were not trained in life skills education. Teachers had a negative attitude towards the teaching of life skills education and the critical learning resources were available but they were grossly inadequate. The study concluded low preparedness of teachers and school managers in the implementation of life skills.

Professional training requires a purposely planned program of study prepared by experts which has the approval of competent authority. This should provide for adequate training on all aspects of the subject in order to be effective in performing the task. Through life skills education, one can move towards positive and holistic approaches in order to evaluate the new generation and through them the future generation (WHO, 1999). Life skills education will be effective only when people apply the skills which they have learnt. As noted by Francis (2007), life kills education should enable the learner develop a concept of oneself as a person of worth and dignity. It should help one understand oneself and lead to growth in personal responsibility. It empowers youth in challenging situation like leadership responsibilities, communication, intellectual capacity, self-esteem, inter-personal skills among others (Francis, 2007).

During the revision of the curriculum in 2003 in Kenya, life skills were integrated and infused into various subjects. Subsequently, it was incorporated into teaching-learning materials. To strengthen life skills education, Kenya Institute of Education (KIE) which is now Kenya Institute 
of Curriculum Development (KICD) has undertaken a number of activities aimed at building the capacity in primary and secondary teachers to main stream the life-skills education. This was as a result of the monitoring exercise on HIV and AIDS project by KIE, which established that there existed a gap between knowledge and behavior change among the learners. Life skills education was hence seen to be the stop-gap measure (Wasamu, 2011). In order to have an effective implementation of life skills education, there is a need to have professionally trained and skilled personnel (Kaimuri, 2007).

The life skills education syllabus for secondary schools provides for interactive approach in teaching. It aims at equipping the learner with psycho-social competencies that will help one make informed decision, solve problems, think creatively and critically, communicate effectively, build healthy relationships, empathize with those in need and manage his or her life in a healthy and productive manner. It is a comprehensive behavior change approach that concentrates on the development of psycho-social skills needed for life. The course goes beyond providing information to the development of the whole individual (MOE, 2008). Under the Secondary Education Curriculum, Life Skills Education syllabus only recommends the content provided encourages teachers to as far as possible, teach using local experiences and examples emerging from their villages, neighborhood, nations and world at large (MOE, 2008). The syllabus however does not empower the teacher with the specific skills to do this. In his research study on the challenges facing life skills education in secondary schools in Trans-Nzoia west District in Kenya, Abobo, (2012) indicated inadequacy on the teachers training and use of teaching-learning materials on the implementation of life skills education in secondary schools. He concluded that effective teaching was hampered by school context factors where he viewed teacher's training on life skills as "The best strategy for ensuring effective implementation of life skills curriculum in secondary schools" (Francis, 2012).

UNICEF (2007) has life skills learning resources which include among others 27 story books of various authors for teachers, life skills handbooks by Hanbury among other books. One can also access resources for training adults and young leaders as participation practitioners, Alaloum video, building blocks of life and empowers them to make positive change in their lives. The Child Social and Financial Education (CSFE) program balances personal and social awareness with social planning, savings and entrepreneurial skills. One can also access relevant books for purchase by Hanbury (2000-2009). The website has also activity based curriculum like storytelling, songs, dance, games, savings, clubs and financial and community improvement enterprises. There are free life skills activity sessions and other resources, talks, training and mentoring (Hanbury, 2008).

In South Africa, life skills are conveyed to children to value their own individuality and respect the dignity and rights of others. Helpers can assist clients to learn self-helping skills to manage the present and prevent and manage future problems. Life skills in the context of helping approach for example are divided in the following sections; Importance of Life Skills to adolescents, classification of life skills, effective life skills, and life skills education programmes among others (Motepe, 2006). With the assistance from UNICEF, Kenya Countries Office (KCO), Kenya Institute of Curriculum Development (KICD) in 2002 developed 40,000 sets of instructional materials on life skills education which included life skills for youth and facilitator's handbook. In the Secondary Curriculum, life skills education was infused and integrated in the teaching of other subjects (UNICEF Kenya, 2010).

In response to the challenges faced in recent times of Kenya like the post-election violence of 2007-2008, the Kenyan Government introduced life skills education with the understanding that the violence emanated from intolerance, lack of nationalism among other ills which the education 
system could not cure. Some of the issues addressed by the "WAKI commission" (2010), which tried to find out the causes of Post-Election Violence (Wasamu, 2011), local publishers like Kenya Literature Bureau, Oxford and East African Education publishers came up with books to teach the subject (Wasamu,2011).

The Secondary Life Skills Education syllabus provides for national goals, secondary education objectives, general objectives and specific objectives besides the contents which guide teachers in the effective teaching of life skills at secondary level (MOE, 2008). The syllabus suggests learning resources like charts, relevant videos, magazines, case studies, short plays, charts with core-living values, flash cards, model of human body, resource person, story-telling, books, learning experiences, audio-visual, developmental charts, newspaper cuttings, textbooks, charts showing emotional expressions, inflated and deflated balloons, group tasks, charts with slogans, watch, cartoons, television, picture code, pressure line forms, journals, charts showing situations that call for effective communication, risky situations analysis cards. Teachers are also encouraged to use local experiences and examples emerging from their villages, neighborhood, nation and the world at large (MOE, 2008).

Mutegi, (2012) established that the teaching learning materials and time allocated to the life-skills education were inadequate. This was in her research study on the factors influencing the implementation on life skills education in public primary schools in Athi River district in Kenya. Her recommendations emphasized on addressing the two issues besides investigation on the influence on gender of the teacher on life skills education implementation (Mutegi, 2012). This study was to establish the availability of teaching learning materials and lack of which could undermine effective teaching.

Lewin, as cited by Cole (2005) indicates that the foundation of an individual value system and the action that springs from him is the individual set of values, which is formed under various influences in the external world. He further says that individual's personal attitudes are the platforms in which perceptions are formed, opinions and judgements are made and actions taken. Therefore, the school management and teachers' attitude towards implementation of life skills education depends on the initial government policies on the teaching of life skills education, and the criteria upon which schools' performance is evaluated. The 8-4-4 Education System in which life skills education is taught was received with mixed reactions from the stake-holders including teachers. As highlighted by Olwoch, (2006) the implementation process was wanting. This was ragged with pre-test program skipped due to pressure for quick implementation of the program, and the system went to school raw as it were (Olwoch, 2006). Kaimuri, (2007), in her research project on the factors influencing the implementation of life skills Education in primary schools in Lang'ata division after establishing the infusion and integration as inadequate, also recommended that life skills education should be taught as a stand-alone subject. Among other recommendations, she also recommended for further research which should include a study on the attitude of teachers towards the teaching of life skills in schools.

Age 0 to 19 is critical formative years for the development of behavior and skills for an individual (Bandura, 1982). Learners including those with special needs face varied challenges which need to be addressed. These include negative peer pressure, gender bias, violence, early marriage, teenage pregnancy, indiscipline, career choices, early sexual onset, drug and substance abuse, rape, incest and HIV/AIDS pandemic. These challenges are compounded by for example changes during adolescence, lack of positive role models, negative mass media influence and inadequate and unreliable sources of information, especially on human sexuality. These challenges render the youth vulnerable to social and health risks like sexually transmitted diseases, HIV infections etc. For historical reasons, traditional families and educational ties have largely broken down, thereby leaving young people vulnerable (Brown, 2003). Media and culture awareness have also been 
suggested as essential adjusts to the life skills approach (ICAP, 2000). This however does not address issues related to social environment economics and opportunity, which also need to be addressed given their impact on the choices, and decisions that people make, e.g. about drinking and health in general (ICAP, 2000).

UNICEF executive director to the global consultation on addressing inequalities in the post 2015 inequality agenda, nationwide school assessment shows the great need for investment in life skills based education, for example Libya, Mali, Thailand, Syria and Sudan. These include HIV/AIDS prevention, Health, Sanitation, Peace education and the environment, Water, hygiene, gender equality besides basic education (UNICEF, 2008). In an effort to offer guidance in implementing life skills based education, UNICEF has created a special website. This website shows cases promising examples of life skills based education around the world. It also has catalogues studies that have evaluated skills based programs. It also provides practical tools and materials for those ready to implement life skills based education e.g. HIV/AIDS prevention, health education, Human Rights and Social issues, and violence prevention, peace building and education for development (Sabina, 2012).

In South Africa, a wide variety of skills have been selected for inclusion of life skills programme for adolescents. These include acquisition of self-reliant skills, decision making, problem solving, critical thinking, self-awareness, assertiveness, training, communication and conflict resolution. They also include the ability to facilitate a sense of belonging which play a key role and development of self-esteem (Motepe, 2006).

Under the topic of "Mainstreaming Cross-cutting Issues", one of the six objectives for the KEMI (Kenya Education Management Institute) course unit of Secondary school managers was for the learner to be able to "identify three categories of Life Skills" (KEMI, 2011).Under the Kenya Sector Support Programme, the Ministry of Education anticipates to carry out a national baseline survey on life skills education after every four years (MOE, 2009).

\section{Research Methodology}

The study adopted a mixed research methodology. This is where both qualitative and quantitative data had equal weight, and the collection of data involved mixing of research questions (Creswell, 2009). Greater emphasis was laid on the findings of qualitative data that was supported and reinforced with the quantitative findings on the secondary schools' readiness in the implementation of life skills education in Trans-Nzoia County.

\section{Results and discussion}

\section{A. Demographic data Analysis}

As indicated in figure 2, among the 51 schools that were visited, boys schools were 4, comprising of $7.8 \%$, girls schools were 8 , comprising of $15.7 \%$ and mixed schools were 39 which formed $76.5 \%$. This reflected the trend of secondary schools in the county where majority of them were mixed schools. The total number of teachers interviewed was 129 . These were 51 head teachers, 51 guiding and counseling heads of department and 27 life skills education teachers. The 27 teachers assigned to teach life skills were those from the 18 schools that implemented it. Some schools had more than one teacher teaching the subject, an assignment which was additional to their official workload. 


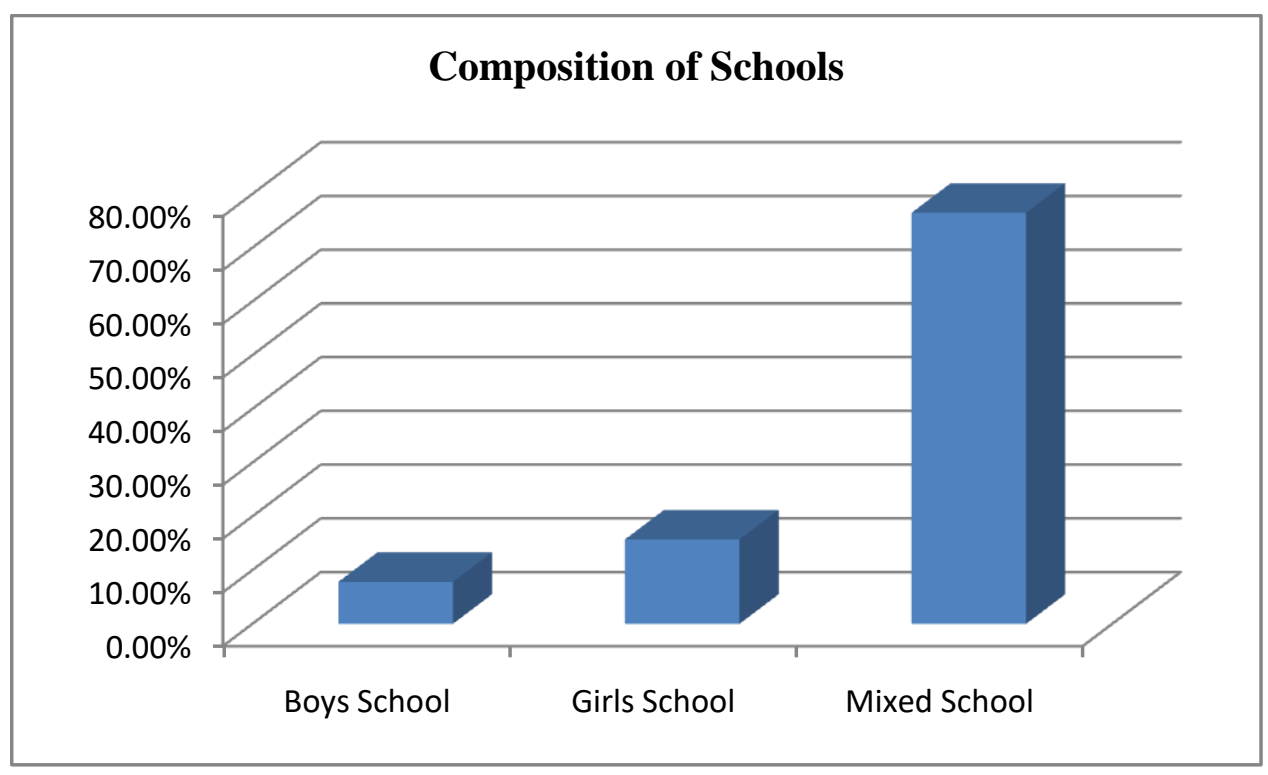

Figure 2: Composition of Schools

In their work stations as indicated in figure 3, 12 which translated to $9.30 \%$ of teachers had served between 0-4 years, 66 which translated to $51.16 \%$ of teachers had served between $5-9$ years while 51 that translated to $39.53 \%$ of teachers had served for 10 and above years. This implied that more than half of the teachers teaching in secondary schools of Trans-Nzoia County have a teaching experience of 5-9 years. This meant that over $90 \%$ of teachers had a teaching experience five and above years and hence were experienced enough in terms of length of service to effectively implement life skills education.

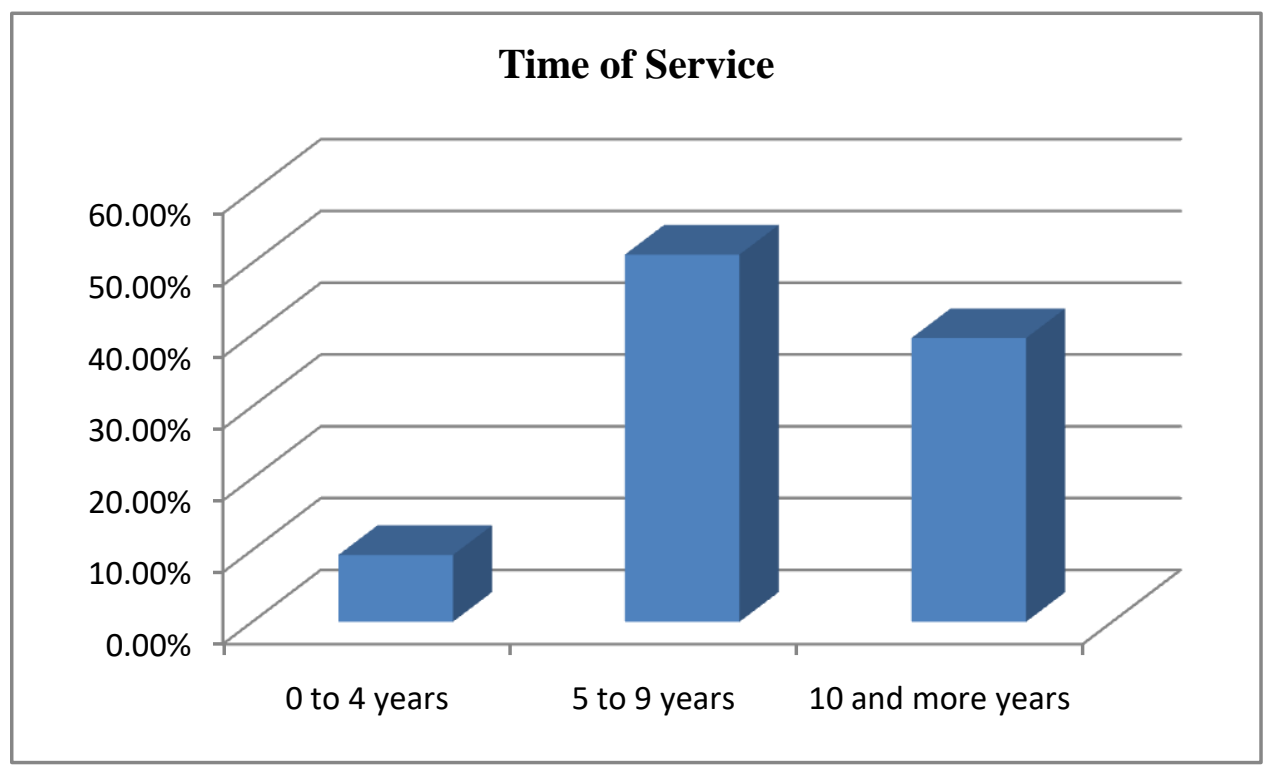

Figure 3: Length of service in the station.

On qualifications levels of respondents as indicated in table 5, 10 which translated to $7.75 \%$ had diploma, 63 who formed $48.84 \%$ had degrees, while 56 who formed $43.41 \%$ had postgraduate qualifications. This implied that most of the secondary school teachers in Trans-Nzoia County 
had degrees with a good number of them having post graduate qualification. This implied that majority of the teachers were qualified enough in terms of academic qualifications to effectively teach life skills.

Table 5: Qualification levels

\begin{tabular}{lcc}
\hline Categories & Frequency & Percentage \\
\hline Degree & 63 & $48.84 \%$ \\
Postgraduate & 56 & $43.41 \%$ \\
Diploma & 10 & $7.75 \%$ \\
Total & $\mathbf{1 2 9}$ & $\mathbf{1 0 0 . 0 0 \%}$ \\
\hline
\end{tabular}

\section{B. Thematic analysis}

As indicated in Table 6, 33 schools which formed $64.7 \%$, of the schools that were visited did not implement life skills education. Only 18 schools, which translated to $35.29 \%$, taught life skills education.

Of the 33 schools that did not teach life skills education, 14 schools had life skills education timetabled, while 19 schools did not have it on the timetable. The average score therefore for life skills curriculum implementation in Secondary Schools of Trans-Nzoia County was 35.29\% which translated to below average.

Table 6: Life Skills Curriculum Implementation

\begin{tabular}{lccc}
\hline Schools & Frequency & Total & Percentage \\
\hline $\begin{array}{l}\text { Schools that implemented life skills } \\
\text { education }\end{array}$ & 18 & 51 & $35.29 \%$ \\
$\begin{array}{l}\text { Schools that timetabled life skills } \\
\text { did not implement it }\end{array}$ & 14 & 51 & $27.45 \%$ education but \\
$\begin{array}{l}\text { Schools that neither timetabled } \\
\text { nor implemented life skills education }\end{array}$ & 19 & 51 & $37.25 \%$ \\
Total & $\mathbf{5 1}$ & $\mathbf{5 1}$ & $\mathbf{1 0 0 . 0 0 \%}$ \\
\hline
\end{tabular}

\section{Teachers Training on Life Skills Education Implementation in Secondary Schools of Trans-Nzoia County.}

The mode of training in the implementation in life skills education was limited to capacity building programs of one week. Shiundu and Omulando (1992), indicate that Pre-service and inservice training play a vital role in curriculum implementation A teacher is the most important person in teaching, who sees that educational programmes are successfully implemented by organizing and managing the learning experiences and environments (Shiundu and Omulando, 1992). Orodho (2013) recommended that there was a need for continuous staff development in order to enhance quality curriculum implementation.

The mode of training for the implementation of life skills education was therefore inadequate. 


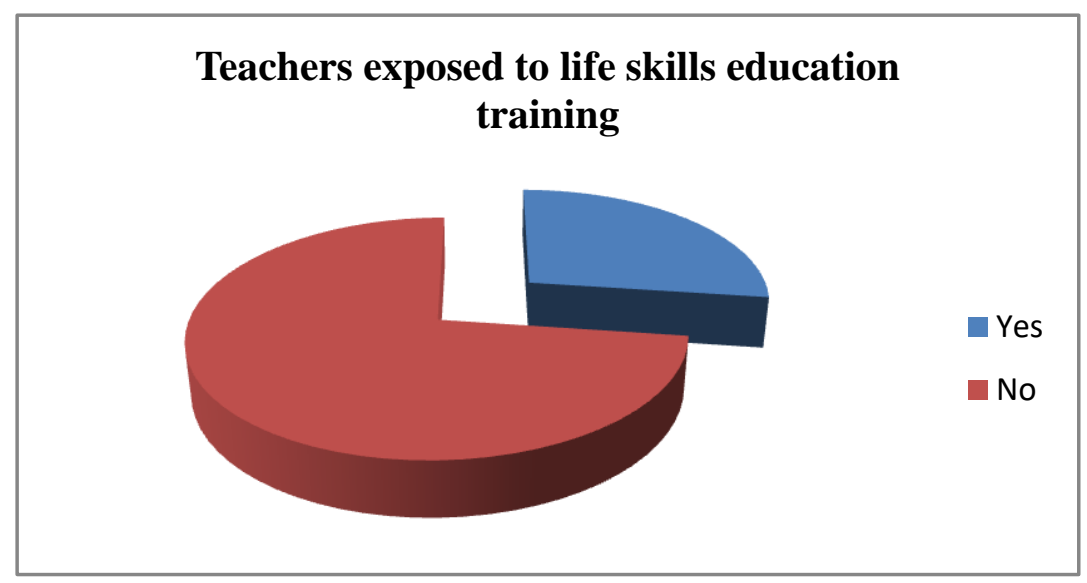

Figure 4: Teachers exposed to training in the implementation of life skills education

As indicated in figure 4, 94 which translated to $72.87 \%$ of the respondents were not exposed to any form of training. Only 35 respondents who formed $27.13 \%$ of the respondents were exposed to a one week capacity training program. This implied that schools' readiness in the implementation of life skills education in secondary schools of Trans-Nzoia County in terms of training was inadequate. Similar findings had been established in Abobo's research (2012), on the challenges facing life skills Education in Secondary schools of Trans-Nzoia West District in Kenya, which indicated inadequacy in teachers' training towards the implementation of life skills education.

Inadequacy in teachers' training was also reflected in the teaching methods used. Only three methods, namely case study, use of resource persons and use of discussions were used.

\section{Teaching Skills (methods) used.}

As indicated in figure 5, the only method used by all schools was discussion. This was in line with Life Skills Education syllabus and teachers guide which suggest that teachers use participatory teaching and learning methods in which the learners identify their own problems, discuss solutions, plan and carry out effective action programmed (MOE, 2008).

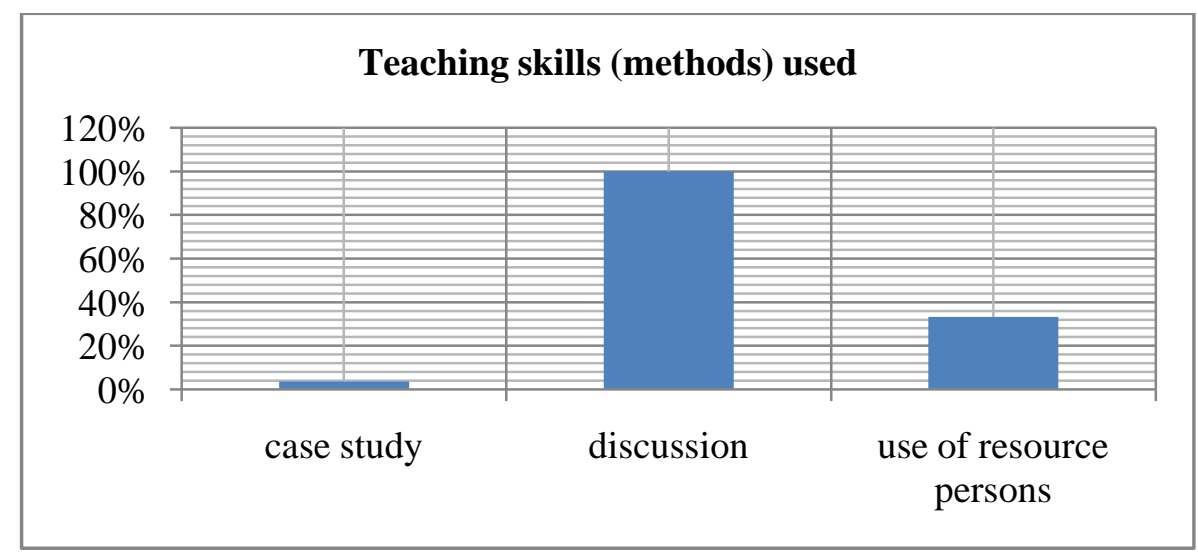

Figure 5: Teaching skills (methods) used

There were two other methods used, namely resource persons and case study, but on a minimal level. 9 respondents that comprised of $33.33 \%$ teachers used resource persons, while only 1 teacher that formed $3.70 \%$ used case study. 
None of the schools taught using field visits, panel discussions, storytelling, songs, debate, role play, games, poetry recitals, drama, local experiences and examples emerging from their villages, neighborhood and the world at large; as encouraged by the life skills education syllabus (MOE, 2008). Also, Hanbury's (2008) suggested activity based curriculum like storytelling, songs, dance, mentoring, and alaloum (comedy) videos among others were never used. The methods used therefore were not adequate to effectively realize the interactive approach in teaching, for comprehensive behavior change approach that concentrates on the development of psychosocial skills needed for life, as advised by Life Skills education syllabus (MOE, 2008).

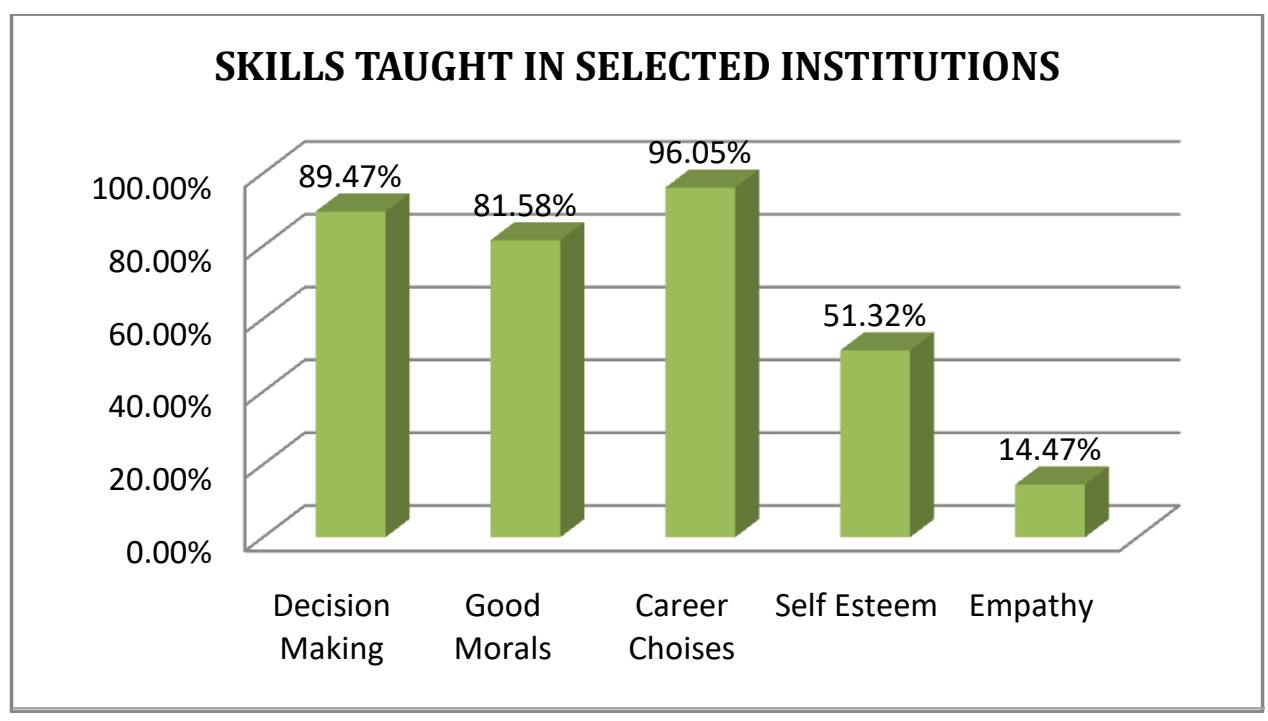

Figure 6: Skills taught in selected institutions

From the whole life skills secondary coursework, there were only five topics or skills taught directly through life skills lessons and also indirectly through guidance and counseling programs from a total of 76 respondents. These as indicated in figure 6,73 teachers which translated to $96.05 \%$ taught career choices, 68 who formed $89.47 \%$ of the teachers taught decision making skills, 62 teachers which translated to $81.58 \%$ of the teachers taught good morals, 39 teachers who formed $51.32 \%$ of the teachers taught self-esteem and only 11 teachers which translates to $14.47 \%$ of the teachers taught empathy.

Other skills indicated in Kenya Institute of Curriculum Development syllabus (MOE, 2008) and course books, despite their importance and relevance, like problem solving skills, critical thinking, self-awareness, assertiveness, communication skills, conflict resolution, coping with emotions, among others were never taught.

\section{E. The Availability of Teaching and Learning Materials and Infrastructure for the Implementation of Life Skills Education in Secondary Schools of Trans-Nzoia County.}

Among the schools that taught life skills as indicated in figure 7, 14 out of which translated to $78 \%$ had the schemes of work, 13 which translated to $72 \%$ out 18 schools had just a copy of the syllabus book, then the schools that had lesson plans and record of work were 6 which translated to $33 \%$. 


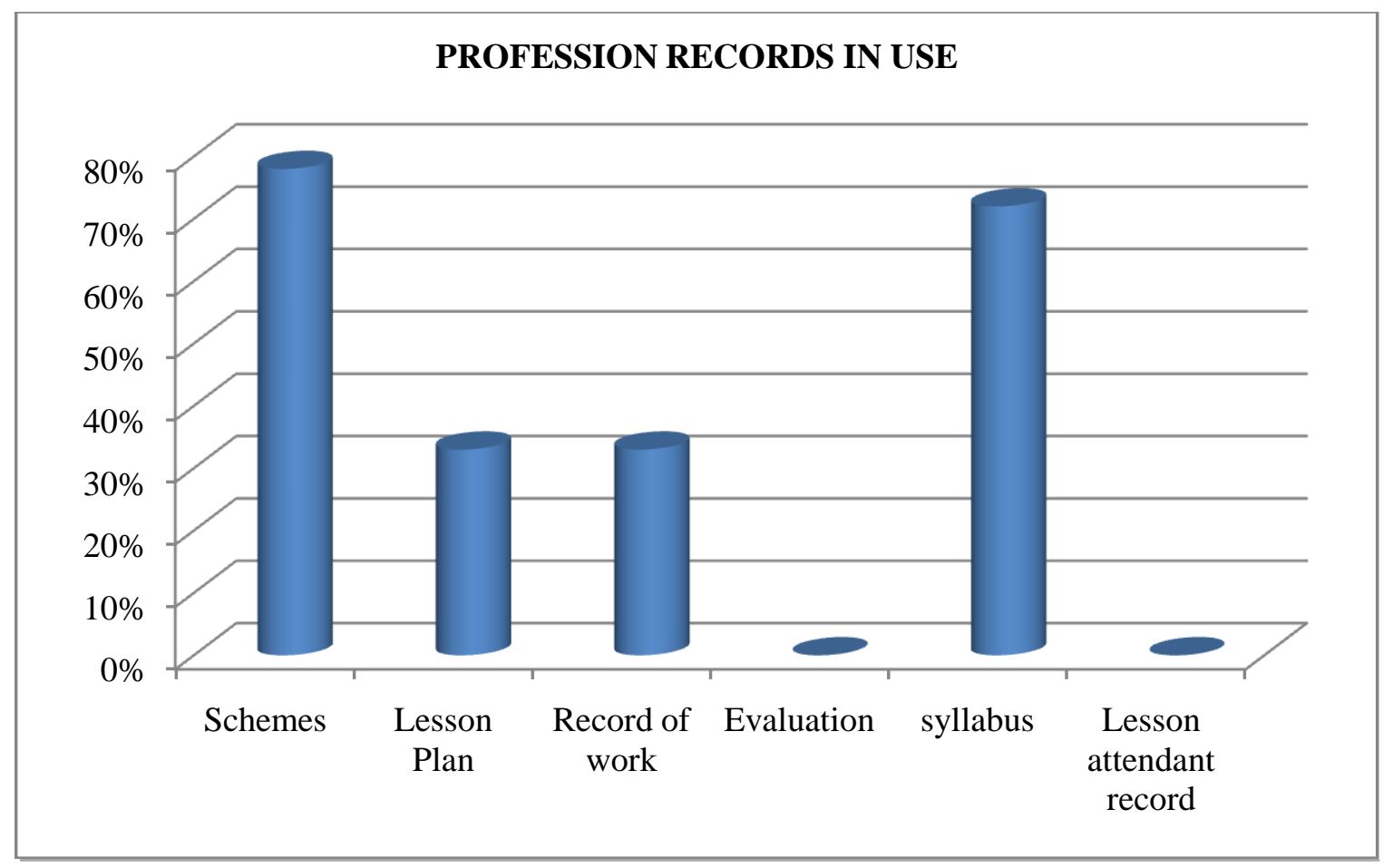

Figure 7: Professional records in use

None of the schools had either lesson attendance records or evaluation records. The total average score of the professional record in use was found to be $43.33 \%$ which translated to below average. With no evaluation records and no records of lesson attendance, the researcher was unable to ascertain whether actual learning took place or not, as one may not be sure whether the lessons observed by the researcher usually took place as observed.

Lack of evaluation records was in reflection to the findings of end of decade evaluation (EDA) team of the achievement of EFA (Education For All) goals in 2012, which conceded that these goals remains difficult area to conceptualise and measure due to the complex nature of life skills and lifelong learning, and the fact that quantitative benchmarks for these programmes are not yet well defined nationally and internationally. The Evaluation team went further to lament that in the absence of policy frameworks and elaborate curricular and programmes that addresses life skills issues holistically, a shared understanding of this concept across formal and non-formal and informal education in Kenya is lacking (Republic of Kenya/UNICEF, 2012). 


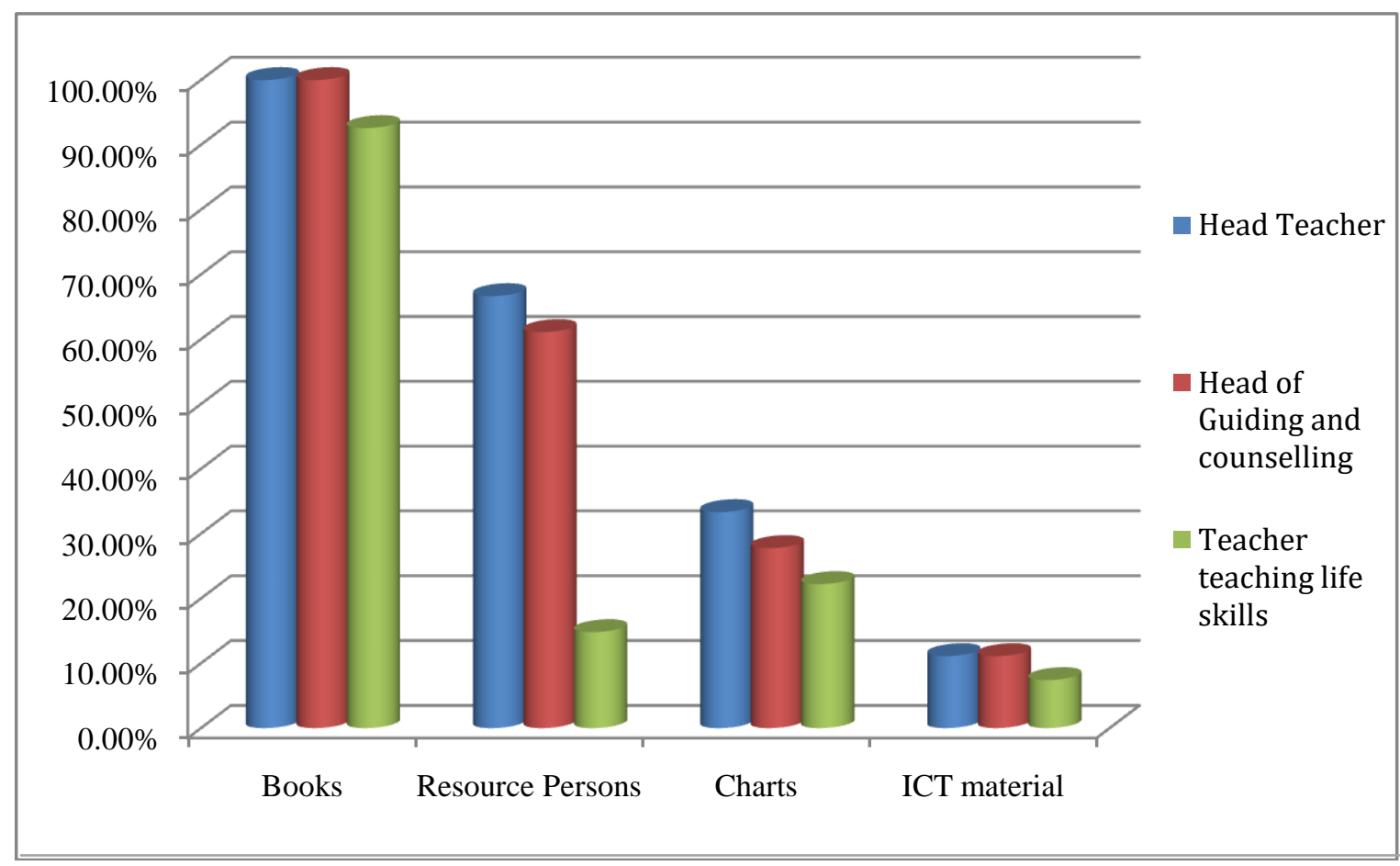

Figure 8: Facilities used in imparting life skills

As indicated in figure 8 the use of text books was observed as the most common facility used to impart life skills education in secondary schools of Trans-Nzoia County. Information bias was noted where 12 out of 18 Head teachers indicated the use of resource persons, 11 out of 18 guiding and counseling Heads of Department indicated the use of resource persons and 4 out of 27 teachers who taught life skills in the 18 schools indicated the use of resource persons. The 2 schools that indicated the use of ICT (Information Communication Technology) facilities were those who had head teachers teaching life skills. To address the above indicated limitation, observation of the lessons being taught, document analysis with the use of information checklist were used.

The use of charts was also minimal with 6 out of 27 life skills teachers, and 6 out of 18 head teachers indicating the use of charts. The average score of the facilities and infrastructure in use, in the implementation of life skills education was found to be $43.33 \%$ which was below average. The other teaching learning resources suggested by the life skills education syllabus (MOE,2008), like journals, group tasks, newspaper cuttings, learning experiences, storytelling, flash cards, model of human body, short plays, case studies, and magazines among others were never used. The observed facilities were therefore inadequate to rely on for effective implementation of life skills education among the learners.

Inadequacy in the use of teaching-learning materials and on the implementation of life skills education in secondary schools was also highlighted by Abobo and Orodho (2014). In their Assessment of the level of preparedness of teachers and school managers in implementing life skills education in Trans-Nzoia West District Kenya, Abobo and Orodho (2014), established that critical teaching learning materials were available but were grossly inadequate in most of the secondary schools studied. 


\section{F. Teachers Attitude towards the Implementation of Life Skills Education in Secondary Schools of Trans-Nzoia County.}

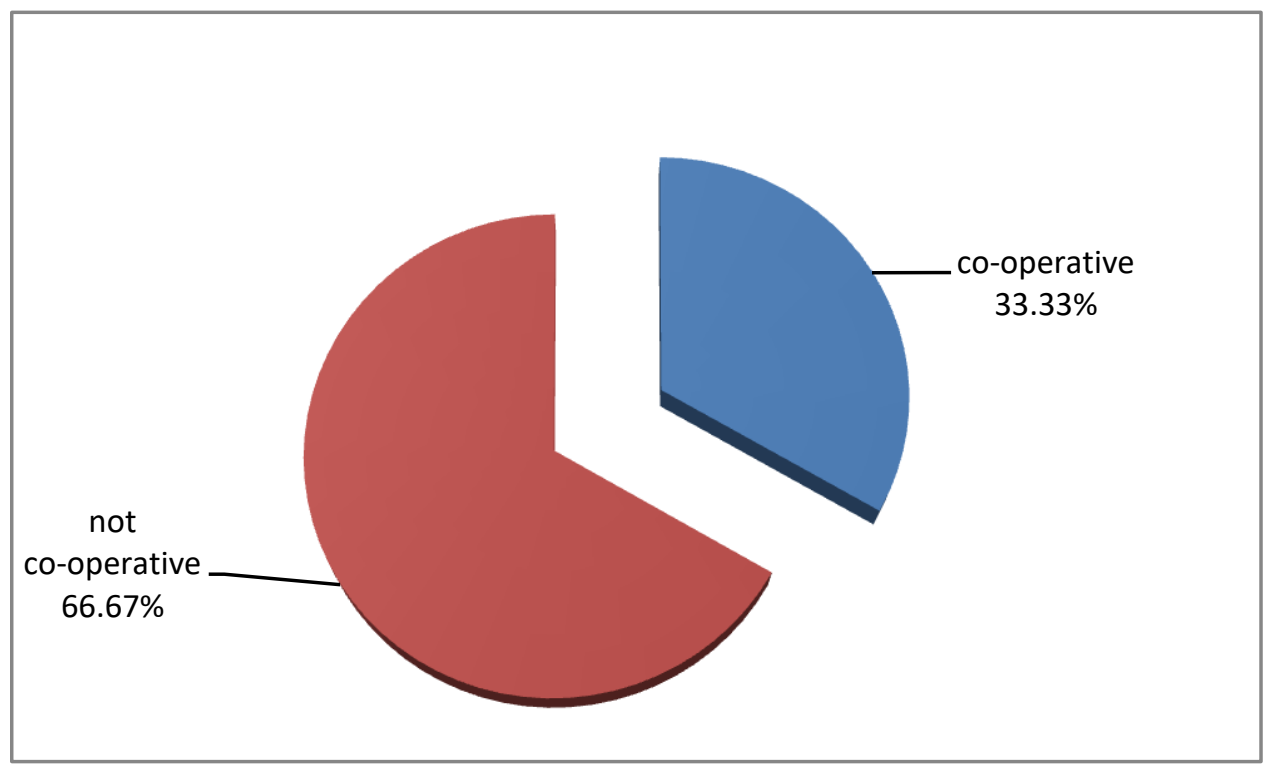

Figure 9: Teacher's co-operation in the implementation of life skills education.

In their response to whether the head teachers considered the teachers assigned to teach life skills co-operative or not, 12 out of 18 which translated to $66.67 \%$, indicated that teachers were not cooperative as shown in figure 9 . This means that a higher percentage of teachers were not ready to implement life skills education. Their attitude therefore towards the implementation of life skills education in secondary schools of Trans-Nzoia County was negative.

Kaimuri's recommendations in her study (2007) among others, was further research which should include a study on the attitude of teachers towards the teaching of life skills in schools (Kaimuri, 2007). As indicated in figure 4.12, among the challenges faced in the implementation of life skills education in Secondary schools of Trans-Nzoia County was negative attitude. This was associated with $10(55.56 \%)$ out of 18 schools indicating no commitment. All the schools indicated lack of enough time allocated to the teaching of life skills. Lack of enough time allocated to teach life skills had also been highlighted by Mutegi's study on the factors influencing the implementation of life skills education in public primary schools in Athi River District in Kenya, which established that the teaching learning materials and time allocated to the life skills education was inadequate (Mutegi, 2012).

\section{G. School Management Attitude towards the Implementation of Life Skills Education in Secondary Schools of Trans-Nzoia County.}

The researcher sampled out 51 schools for data collection. From the findings as indicated in table 7, only 18 schools among them implemented life skills, while 33 schools did not. Out of the 33 schools that did not implement life skills education 19 of them did not have life skills time tabled. From these schools, 2 head teachers and 7 guiding and counseling heads of department needed to be explained to what life skills was all about before they could give their response. This category of schools did not have any teacher assigned to teach life skills. The researcher therefore got zero responses from the 33 anticipated teachers assigned to teach life skills. The concern in the statement of the problem of this study by the Trans-Nzoia County Quality Assurance and 
Standards' Secondary Schools assessment Report indicated that teachers used life skills lessons to teach other subjects and in some schools life skills was not even time tabled (Okayo, 2012).

The other 14 schools had life skills timetabled but no teaching was taking place, with the main reason being staff shortage with the need to concentrate on examinable subjects. In one school for example, teachers employed by the Teachers' Service Commission were 2 after one had just died and another school had 3. The two schools were up-coming whose Board of Management employed unqualified teachers, some who were university students and others form four graduates. This was a limitation in that the researcher was only able to collect data from the 18 schools that implemented life skills education. Apart from acute staff shortage, examination pressure may be contributing to schools unwillingness to implement life skills education. "The Principal," the Secondary Heads professional magazine recognised teachers' performance based on Kenya Certificate of Secondary Education (KCSE) mean score of learners in identifying their Teacher of the year/Principal of the year Award (TOYA/POYA) (Awiti, 2012). The Teachers Service Commission (T.S.C.) in their "Image" magazines volume 18 (2012) and volume 19 (2013) recognized "Heroes and Heroines" based on the teacher's mean score in the KCSE (Kenya Certificate of Secondary Education) performance (Karanga, 2012, 2013). Siringi (2014) highlighted public condemnation as "shame" of schools which performed poorly in National Examinations.

Table 7: Criteria used in assigning the teaching of life skills education

\begin{tabular}{llcc}
\hline Criteria & Frequency & Total & percentage score \\
\hline Willingness & 4 & 18 & $22.22 \%$ \\
Training & 5 & 18 & $27.77 \%$ \\
Handpicking & 9 & 18 & $50.00 \%$ \\
Total & $\mathbf{1 8}$ & $\mathbf{1 8}$ & $\mathbf{1 0 0 . 0 0 \%}$ \\
\hline
\end{tabular}

The 18 schools that implemented life skills education as indicated in Table 7, 9 which translated to $50 \%$ of head teachers just handpicked teachers to teach life skills without considering the training or the willingness to teach. 5 , who formed $27.7 \%$ of head teachers considered training, while only 4 that formed $22.2 \%$ of head teachers considered willingness to teach. This implied that half of the Head teachers were not keen to have life skills implemented with the seriousness it deserves. 


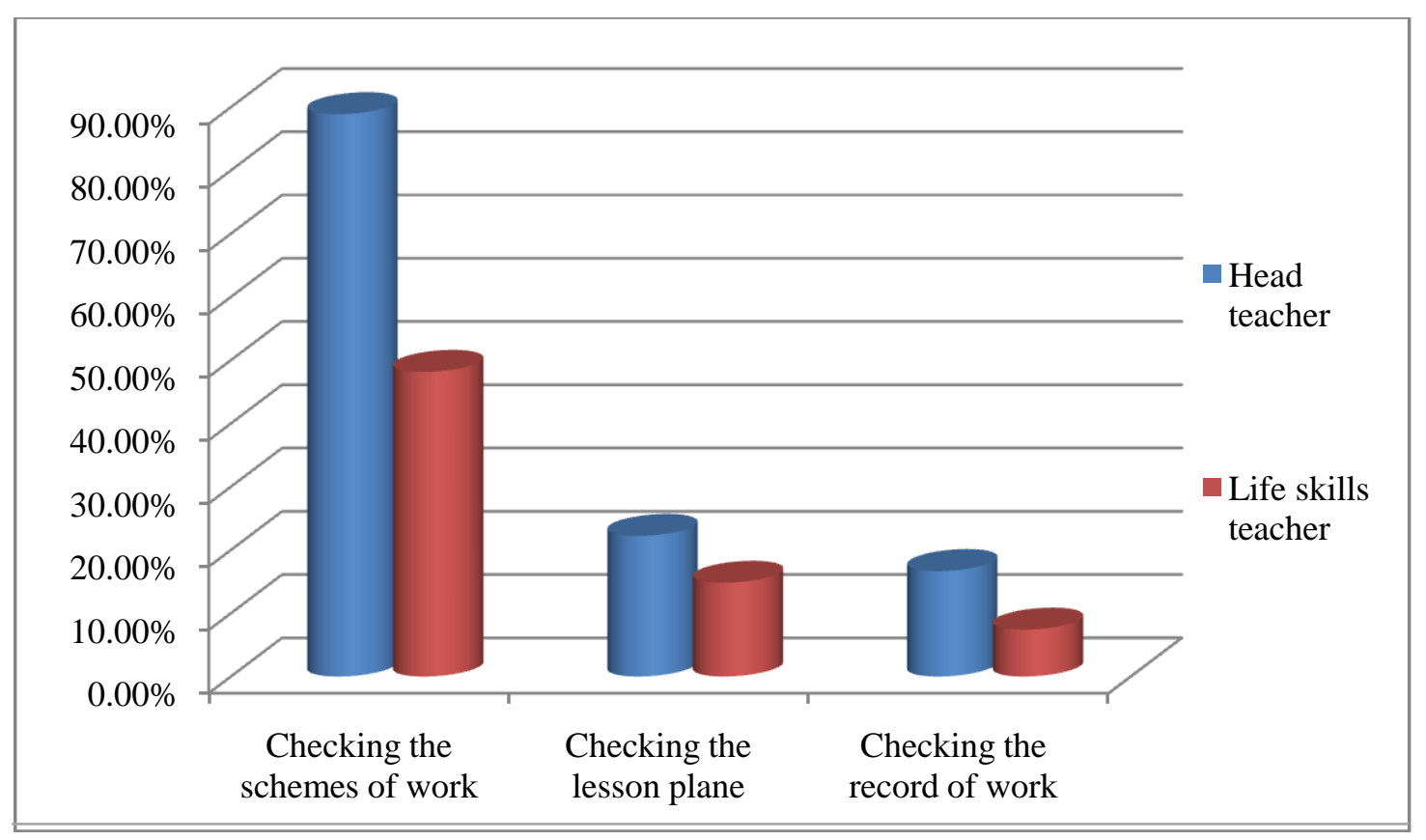

Figure 10: Method used in supervising the implementation life skills education

As indicated in figure 10, there was information bias in the methods used by head teachers in supervising the implementation of life skills education. 16 out of 18 head teachers indicated that they checked schemes of work, while 13 out of 27 life skills teachers confirmed the same. Also 3 head teachers indicated that they checked record of work while 2 life skills teachers confirmed the same. This means therefore that some head teachers did not give reliable information and hence were not sincere in their commitment to enforce the implementation life skills education. 4 head teachers indicated they checked lesson plans. One of the disadvantages of the use of structured interview as indicated by Kombo and Tromp (2006), was where respondents may give answers acceptable or will impress the researchers ( Kombo and Tromp, 2006).

The information bias was addressed by the use of document analysis with the use of information check list, where the study further noted that records like evaluation records, lesson attendance records among others, were never checked. The average score for the head teachers' supervision in the implementation of life skills Education in Secondary schools of Trans-Nzoia County was $33.02 \%$ which was below average and hence ineffective. The average score support from head teachers for the implementation of life skills education in Trans-nzoia County was $35.80 \%$ which was below average. 


\section{SUPPORT IN THE IMPLEMENTATION OF LIFE SKILLS EDUCATION}

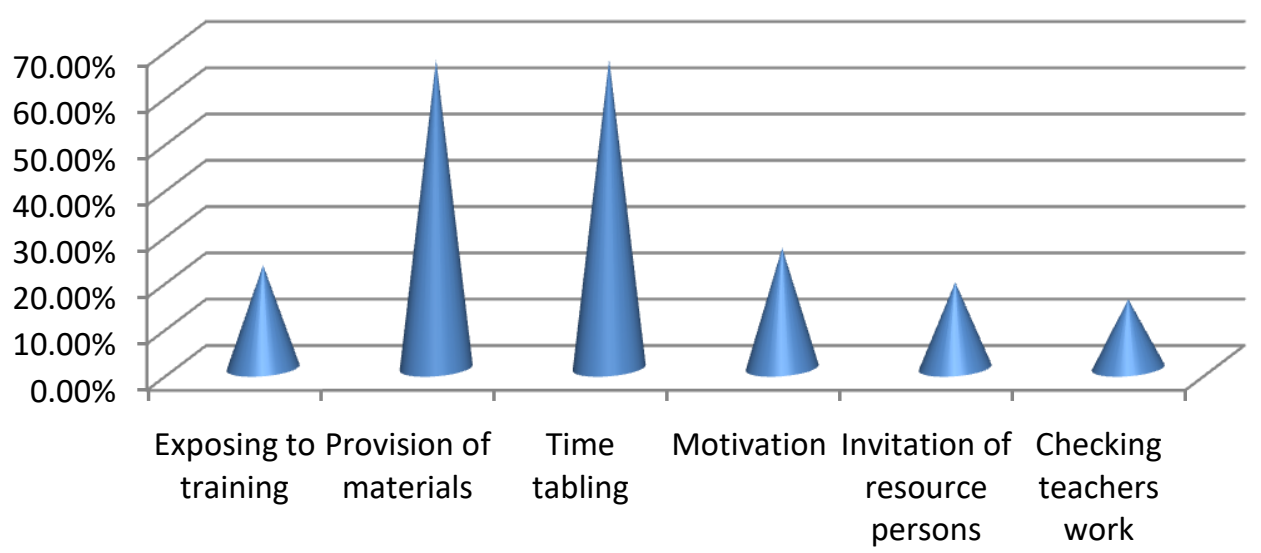

Figure 11: Head teachers support in the implementation of life skills education

As indicated in figure 11, responses from life skills education teachers on how much support they got from head teachers in the implementation of life skills education,

18 which formed $66.7 \%$, out of 27 teachers indicated timetabling of the subject and provision of learning materials. 6 out of 27 teachers which translated to $22.22 \%$ indicated that they were exposed to some training. 7 out of 27 teachers which formed $25.93 \%$ said that they were motivated, while 5 that formed $18.52 \%$ of the teachers indicated that they had the invitation of resource persons. It was only 4 teachers which translated to $14.81 \%$ who said that head teachers checked their work.

From the findings therefore, there was an implication that life skills teachers did not get adequate support from head teachers in the implementation of life skills education in secondary schools of Trans-Nzoia County.

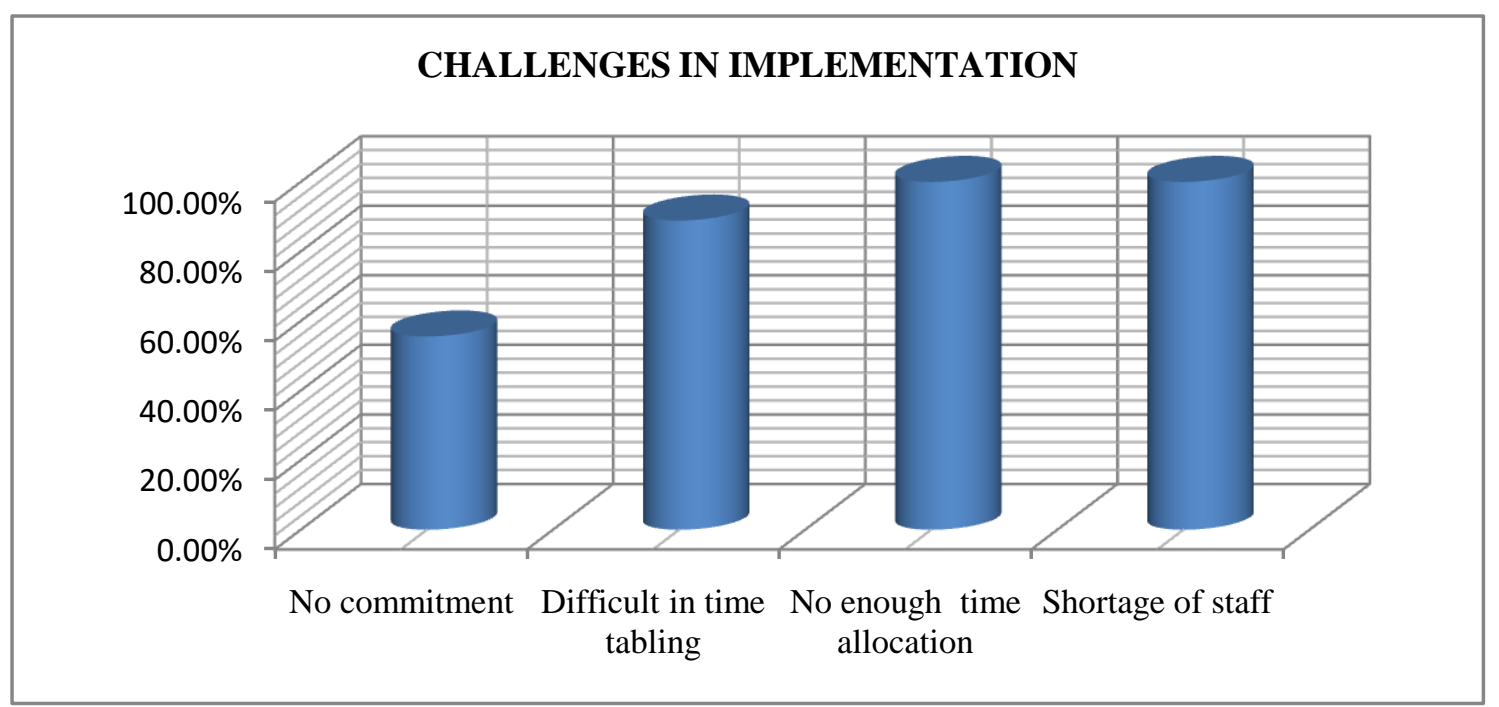

Figure 12: Challenges faced in implementation of life skills education.

As indicated in figure 12, among the challenges experienced in the implementation of life skills education 10 schools which translated to $55.56 \%$ indicated no commitment, 16 schools which 
translated to $88.89 \%$ had difficulty in timetabling life skills education. All the schools indicated shortage of staff, and lack of enough time for teaching life skills. Mutegi's research study had also established lack of enough time allocated for life skills implementation (Mutegi, 2012). Abobo's research study indicated inadequacy on the teachers training and use of teachinglearning materials on the implementation of life skills education in secondary schools of TransNzoia west District (Abobo, 2012). Lack of policy frameworks and elaborate curricular and programs that address life skills issues holistically (Republic of Kenya/UNICEF, 2012), could contribute to such challenges in implementation of life skills education.

\section{Research findings}

The study established that life skills implementation in Trans-Nzoia County was below average, where 33 out of the 51 schools that were visited did not implement it with 19 of them not even timetabling it. From the 19 schools, 2 head teachers and 7 heads of Guidance \& counseling department needed to be explained to by the researcher what life skills was all about before they could give their responses. The 14 schools that had only timetabled the subject had acute shortage of staff with the examination pressure as the main reasons why they were not implementing life skills education. These findings of the study could be attributed to the absence of policy frameworks and elaborate curricular and programs that addresses life skills issues holistically, a shared understanding of this concept across formal non formal and informal and informal education in Kenya is lacking. (MOE/UNICEF, 2012). The findings concur with Githinji's study (2007), which established among others insufficient knowledge and lack of enough life skills education.

The 18 schools that implemented life skills education had only $27.13 \%$ of the respondents having been exposed to one week capacity training program. $72.87 \%$ of the respondents had not been exposed to any form of training in the implementation of life skills education. Abobo \& Orodho (2014), had established that most teachers in secondary schools of Trans-Nzoia West district lacked training in life skills education.

Life skills education curriculum implementation in secondary schools of Tans-Nzoia County in terms of the availability and use of teaching learning materials and infrastructure, syllabus coverage, and teaching methods, was poor. There was no evidence of evaluation and lesson attendance records. All the schools faced the challenge of staff shortage and lack of enough time allocated in the teaching of life skills. Mutegi's study (2012) established that the teaching learning Materials and time allocated to the life skills education was inadequate. Abobo and Orodho (2014) indicated availability of critical learning resources for life skills implementation in secondary schools of Trans-Nzoia West District, but established that they were grossly inadequate. Ineffective implementation of life skills education in Kenya had been established by Kaimuri's study (2007) and Abobo's study (2012).

Teachers' negative attitude towards the implementation of life skills education in Trans-Nzoia County was implied by head teachers indicating that $66.67 \%$ of teachers assigned to teach life skills were uncooperative. Kaimuri's study (2007), among other recommendations was that a study should be carried out on the teachers' attitude towards the implementation of life skills, after establishing ineffective implementation of life skills education. Abobo and Orodho (2014) also established that most teachers in secondary schools of Trans-Nzoia West District had negative attitude towards the teaching of life skills. Elements of school managements' negative attitude towards the implementation of life skills education in secondary schools of Trans-Nzoia County was indicated by 14 out of the 51 schools that were visited which translated to $27.45 \%$ having life skills education time tabled but no teaching was taking place. The indicated schools 
used life skills lessons to teach other subjects. This was the concern by Trans-Nzoia County Quality Assurance and standards' assessment report, that teachers used life skills lessons to teach other subjects (Okayo, 2012).

School managements' negative attitude towards the implementation of life skills education in secondary schools of Trans-Nzoia County was also indicated by the information bias over their supervisory methods and skills. The unreliable information given by some head teachers indicated that they were not sincere in their commitment to enforce the implementation of life skills education. It was also indicated in the criteria used in identifying life skills education teachers, where $50 \%$ of the head teachers just handpicked those to teach without considering their willingness or their competence to handle the subject. $64.71 \%$ of schools visited did not implement life skills education with the major reasons being acute staff shortage and lack of training in the implementation of life skills education. Lack of commitment and hence negative attitude among the principals in the implementation of life skills education in South Africa is highlighted (Prinsloo, 2007).

Perhaps the negative attitude of school management in the implementation of life skills education as established by the study, could be attributed to the acute staff shortage, All the schools visited indicated acute shortage of staff and hence failure to implement or allocate life skills lessons as an additional load to the already overloaded teachers. One of the visited schools for example had 2 and another 3 teachers employed by the Teachers Service Commission (T.S.C.). Since these schools were up-coming, they could only employ unqualified teachers, some who were university students and others were form four leavers. This scenario could concur with Githinji's study (2007), which established among others inadequacy in teaching and lack of enough knowledge in life skills education among teachers. The negative attitude of school management in the implementation of life skills education as established by the study could be attributed to the examination pressure where, Kenya Certificate of Secondary Examinations (KCSE), are used to measure schools performance, yet life skills is not nationally evaluated. "The Principal," the Secondary Heads professional magazine recognized schools' performance based on Kenya Certificate of Secondary Education (KCSE) mean score of learners in identifying their Principal of the year Award (,POYA) besides doing the same for teachers (Awiti, 2012).

The Teachers Service Commission (T.S.C.), in their "Image" magazines volume 18 (Karanga, 2012) and volume 19 (Karanga, 2013) recognized "Heroes and Heroines" based on the teacher's mean score in the KCSE (Kenya Certificate of Secondary Education) performance (Karanga, 2012, 2013). Siringi (2014) highlighted public condemnation as "shame" of schools which performed poorly in National Examinations.

\section{Conclusion}

The findings of the study established that secondary schools in Trans-Nzoia County were far from being ready in the implementation of life skills education. Out of the 51 secondary schools in Trans-Nzoia County that were visited, 33 schools which translated to $64.7 \%$ did not implement life skills education.

The few schools that implemented it did not do so with the commitment and seriousness it deserved. Most teachers who implement life skills education in secondary schools of Trans-Nzoia County highly relied on discussion method. The syllabus coverage was wanting with only five highlighted topics or skills being taught, with the greatest emphasis on career choices. The rest of the seven chapters at each form level, which included communication skills, problem solving skills, critical thinking, among others despite their importance were never taught. The study 
therefore established that the use of teaching learning materials and infrastructure in the implementation of life skills education in secondary schools of Trans-Nzoia County was poor.

Teachers' training on life skills implementation was inadequate and the teaching learning materials and infrastructure were found to be insufficient. Many teachers assigned to teach life skills were uncooperative, an indication of negative attitude. The school administrations' supervision in the implementation of life skills education in secondary schools of Trans-Nzoia County was poor. This implied that most of the head teachers were not ready to enforce the implementation of life skills education in secondary schools of Trans-nzoia County. The study therefore concluded that most of the school administrators and hence the management in secondary schools of Trans-Nzoia County had a negative attitude towards the implementation of life skills education.

\section{Recommendations for further research}

1. Further research should be carried out on other ways of imparting life skills education other than the school curriculum not only to the youth but to the entire society as a whole.

2. A comparative study between the schools that implement life skills education and those that do not should be carried out.

3. Further research should be carried out on the relationship between life skills implementation process and behavior change.

\section{Acknowledgement}

I would like to thank my supervisors Dr. Ruth Thinguri and Dr. Emily Kirwok, for guiding me through this study. Special acknowledgement goes to Kenya National Commission for Science and Technology, Trans-nzoia county commissioner and county director of education for permitting me to carry out my research in Trans-nzoia County and finally the teachers in the sampled schools for their cooperation and support during data collection.

\section{Ethical Consent}

Ethical consideration was sought from the National Council of Science and Technology before proceeding to the field.

\section{References}

1. Greenberg J. 2008. Understanding the Vital Human Quest for Self-esteem. Perspectives on psychological sciences. London. Rutledge.

2. Wasamu, M. 2011. Teaching Life skills: An answer to Kenya's moral decade. The star Newspaper. Tuesday November 22-2011

3. Government of Kenya. 2005. Kenya Sector Support Programme. Nairobi. Government printers.

4. Government of Kenya. 2009. Kenya Sector Support Programme. Nairobi. Government printers.

5. Kelin, K. 2011. Rapid Assessment Report on Effectiveness of Life skills Education in Kenya.

6. UNICEF. 2008. Progress Report for UNICEF'S Education in Emergencies and post- crisis transition programme. Netherlands. Downloaded on www.unicef.org.

7. Republic of Kenya/UNICEF .2012. Education for All (EFA): End of Decade Assessment (2001-2010). Ministry of Education and UNICEF. Nairobi..

8. Prinsloo, D. 2007. Implementation of life Orientation Programmes in the new Curriculum in South African schools: Perceptions of Principals and life orientation teachers. Journal of Education. vol. 27. 
9. Githinji, F. 2007. Perceptions of School Teachers and Pupils on Adequacy of

HIV/AIDS Life skills education. Nairobi and Thika Districts, Kenya. M.ED. Thesis. Kenyatta University. Nairobi.

10. Wasamu, M. 2011. Teaching Life skills: An answer to Kenya's moral decade..

The star Newspaper. Tuesday November 22-2011

11. Ministry of Education. 2008. Secondary Education Curriculum. Life Skills

Education Syllabus. K.I.E. Nairobi.

12. Shiundu and Omulando. 1992. Curriculum Theory and Practice in Kenya. Nairobi. Oxford University Press.

13. Orodho J. and Abobo F. 2014. Life Skills Education in Kenya. Journal of

Humanities and Social Sciences. Vol. 19. Kenyatta University.

14. Orodho, J. 2004. Techniques of Writing Research Proposal in Education and Social Sciences. Nairobi. Masola Publishers.

15. Republic of Kenya/UNICEF. 2012. Education for All (EFA): End of DecadeAssessment (2001-2010) Ministry of Education and UNICEF.Nairobi.

16. World Health Organization. 1999. Partners in Life skills training. Conclusions from United Nations Inter Agency meeting. Geneva. Downloaded on www.speciallearning.com.

17. Francis, M. 2007. Life Skills Education, downloaded on www.changingminds.org.

18. Kaimuri, J. 2007. Factors Influencing the Implementation of Life Skills Education in primary schools in Lang'ata Division. (MED.Thesis) University of Nairobi.

19. Francis, A. 2012. Challenges Facing Implementation of Life Skills Education in Secondary Schools in Tran-nzoia West District. Kenya.

20. Motepe, M. 2006. Life Skills Program for Early Adolescent AIDS orphans. University of Pretoria

21. Republic of Kenya/UNICEF. 2012. Education for All (EFA): End of Decade Assessment (2001-2010). Ministry of Education and UNICEF. Nairobi.

22. Mutegi, L. 2012. School Factors Influencing the Implementation of Life skills Education in Public Primary Schools in Athi River District. Kenya. (MED. Thesis) University of Nairobi.

23. Cole, G. 2005. Organizational Behaviour Theory and Practice. Continuum. Prentice Hall.

24. Olwoch, G. 2006. Essentials of Curriculum Development: Ramco printing works limited, Nairobi Kenya.

25. Bandura A. 1982. The Assessment and Predictive Generality of self-perception of Efficacy. Stanford University.

26. Brown, L. 2003. Secondary School Principal's Report: Dramatic Expansion of Life Skills, Horizons, Research summary, Washington DC Population Council.

27. International Centre for Alcohol Policies (ICAP). 2000. Alcohol Education and its Effectiveness. ICAP Report 16. Washington DC

28. UNICEF. 2008. Progress Report for UNICEF'S Education in Emergencies and post- crisis transition programme. Netherlands. Downloaded on www.unicef.org.

29. Sabina, D. 2012. UNICEF launches schools for Asia to Improve Education for Millions, downloaded from: www.multimedia.org.

30. KEMI. 2011. Long Distance Learning in Diploma in Education Management for Secondary Schools. KEMI Nairobi. 2011

31. Creswell, W. 2009. Research Design: Qualitative ,Quantitative and Mixed Methods Approaches. ${ }^{\text {rd }}$ Edition. Los Angeles; sage Publications.

32. Hanbury, C. 2008. The Life Skills Handbook: An Active learning Handbook for working with children and young people.VSO2002

33. Republic of Kenya/UNICEF. 2012. Education for All (EFA): End of Decade 
Assessment (2001-2010) Ministry of Education and UNICEF. Nairobi.

34. Okayo A. 2012. Trans-Nzoia County Secondary Schools' Quality Assurance and Standards Assessment Report.

35. Awiti, J. 2012. 'The Principal's Magazine'. Kenya Secondary Schools Heads Association (Nairobi press).

36. Kariuki, K. 2012. Teacher's Image; Volume 18. Teachers Service Commission, Kenya.

37. Kariuki, K. 2013. Teacher's Image; Volume 19. Teachers Service Commission, Kenya.

38. Samuel, S. 2014. Daily Nation, Kenya. Thursday March 6- 2014.

39. Kombo, D. and Tromp D. 2006. Proposal and Thesis Writing. An Introduction. Nairobi: Pauline Publications Africa.

40. Okayo A. 2012. Trans-Nzoia County Secondary Schools' Quality Assurance and Standards Assessment Report. 